\title{
Wild and Wonderful: How Both a Local and National Newspaper Framed West Virginia Leading Up to the 2016 Election
}

\author{
Emily Grace Martin \\ West Virginia University, egmartin@mix.wvu.edu
}

Follow this and additional works at: https://researchrepository.wvu.edu/etd

Part of the American Politics Commons, Critical and Cultural Studies Commons, Journalism Studies Commons, Mass Communication Commons, Personality and Social Contexts Commons, and the Social Influence and Political Communication Commons

\section{Recommended Citation}

Martin, Emily Grace, "Wild and Wonderful: How Both a Local and National Newspaper Framed West Virginia Leading Up to the 2016 Election" (2021). Graduate Theses, Dissertations, and Problem Reports. 8342.

https://researchrepository.wvu.edu/etd/8342

This Thesis is protected by copyright and/or related rights. It has been brought to you by the The Research Repository @ WVU with permission from the rights-holder(s). You are free to use this Thesis in any way that is permitted by the copyright and related rights legislation that applies to your use. For other uses you must obtain permission from the rights-holder(s) directly, unless additional rights are indicated by a Creative Commons license in the record and/ or on the work itself. This Thesis has been accepted for inclusion in WVU Graduate Theses, Dissertations, and Problem Reports collection by an authorized administrator of The Research Repository @ WVU. For more information, please contact researchrepository@mail.wvu.edu. 


\section{Wild and Wonderful: How Both a Local and National Newspaper Framed West Virginia Leading Up to the 2016 Election}

Emily Grace Martin

Follow this and additional works at: https://researchrepository.wvu.edu/etd

Part of the American Politics Commons, Critical and Cultural Studies Commons, Journalism Studies Commons, Mass Communication Commons, Personality and Social Contexts Commons, and the Social Influence and Political Communication Commons 

Wild and Wonderful: How Both a Local and National Newspaper Framed
West Virginia Leading Up to the 2016 Election

\author{
Emily Martin
}

Thesis submitted to the College of Media

at West Virginia University

\begin{abstract}
in partial fulfillment of the requirements for the degree of
Masters of Science in

Journalism
\end{abstract}
G. Robert Britten, Ph.D., Chair
Dana Coester, M.A.
Gina Martino Dahlia, M.S.J.
Ann Pancake, Ph.D.
College of Media

Morgantown, West Virginia

2021

Keywords: West Virginia, 2016 Election, Coal, Othering, Suffering, Grounded Theory Copyright 2021 Emily Martin 


\begin{abstract}
Wild and Wonderful: How Both a Local and National Newspaper Framed West Virginia Leading Up to the 2016 Election
\end{abstract}

Emily Martin

During the 2016 Presidential election, journalists from all over the country flocked to West Virginia to try to understand the draw to then-candidate Donald Trump. There is a well-documented history of outsiders flooding the state and its surrounding Appalachian states to attempt to make sense of the current political situation, all while operating off of stereotypes and preconceived notions about the people of the Mountain State. This study aims to determine how stereotyping and the concept of framing or othering - when ingroups create out-groups - were used by a local West Virginia paper, as well as a national newspaper - and how their usage of those concepts compare and contrast - in coverage of the state leading up to the election.

To answer the research question of how the two newspapers differ in their coverage of West Virginia during the time frame of July 19, 2015-Nov. 9, 2016, 119 articles were collected - 100 from the Charleston Gazette-Mail and 19 from The New York Times coded for emergent categories. The categories that were discovered after coding were 'Coal Culture' and 'Suffering,' each with multiple subcategories. When it came to coverage of 'Coal Culture,' the Times was more stereotypical in its coverage and relied more on optics, butthe Gazette-Mail focused more on the economical aspect of mining, not the optics. 'Suffering' was a more common theme in the Gazette-Mail than the Times, but neither paper relied on stereotypes more than the other.

"But you cannot know a place without loving it and hating it and feeling everything in between. You cannot understand a complex people by only looking at data-something inside you has to crack to let in the light so your eyes and brain and heart can adjust properly."

- Silas House, author and Appalachian, 2014 


\section{DEDICATION}

would like to dedicate my work to my family, who has encouraged me and held my hand when it got tough. I would also like to thank my friends, who valued my intelligence and provided some much-needed laughs over the years. As for my committee members, l'd like to thank them for always believing in me and reminding me that both myself and my work are important. 


\section{TABLE OF CONTENTS}

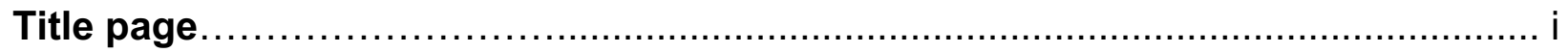

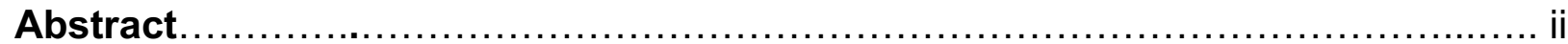

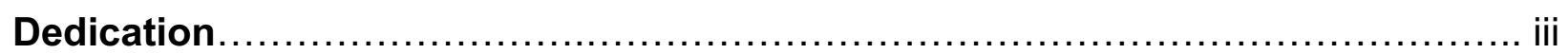

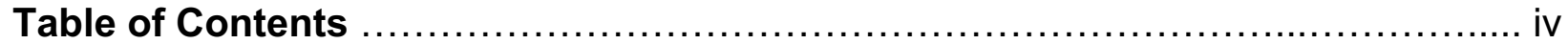

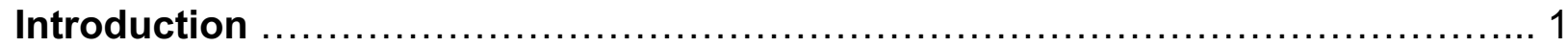

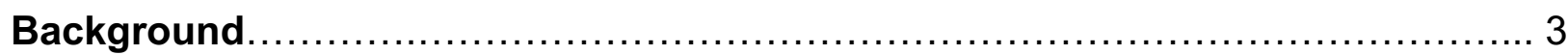

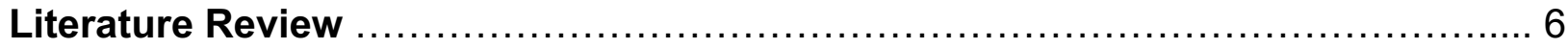

Appalachian Stereotypes in Outsider Media .................................. 6

Framing and News Coverage .................................................. 10

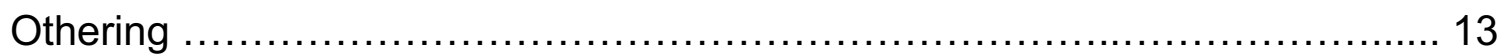

Othering of Appalachia ................................................ 16

Acting Against Self-Interest .......................................... 17

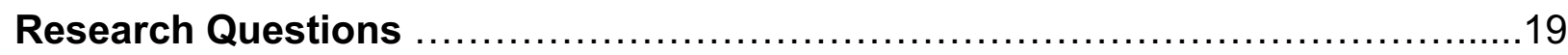

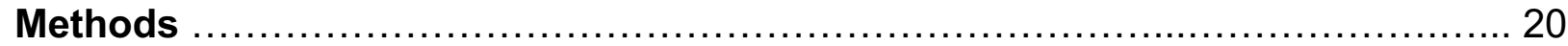

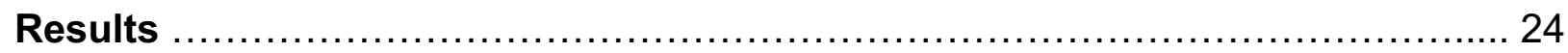

Emergent Categories ......................................................... 24

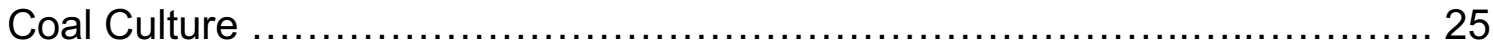

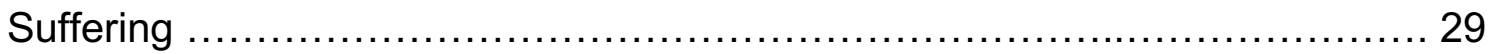

Theoretical and Research Expectations …............................... 31

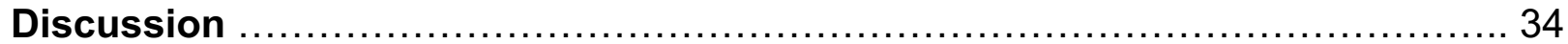

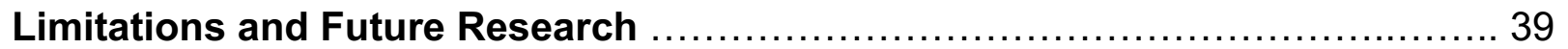

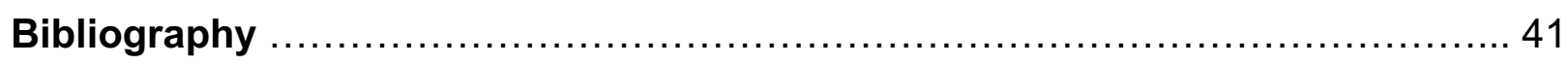




\section{Introduction}

In this grounded theory study (Glaser \& Strauss, 1967), the research examines and compares the coverage of West Virginia leading up to the 2016 presidential election from a local newspaper — the Charleston Gazette-Mail — and a national newspaper — The New York Times - to see how they differ in their portrayals of the Mountain State. This study uses Framing Theory and the concept of Othering in its examination to reflect on typical Appalachian stereotypes often portrayed in the media.

Leading up to the election, it was said that "few places offer such simple electoral calculus...as West Virginia" (Walsh, 2016) and that "there are few better places to understand how Donald Trump could become U.S. president" (Fisher, 2016). Media flocked to the region to try to understand how and why the people of West Virginia felt such vigor for him and why they planned to cast their vote for the real estate tycoon. But the history of media coming to Appalachia to try to make sense of the region and its people dates back to the Civil War when writers would visit and observe the "degenerate social outcasts of the English society" (Brashear, 2016), and it stretches to present day with books like Hillbilly Elegy and television shows like Buckwild.

Appalachians and West Virginians were framed (Entman, 2007) as the "Other," or someone who deviates from the norm (Brons, 2014).

There is very little research done on media coverage of West Virginia from both national and local papers, and no research was conducted during the 2016 presidential election. Only one article compared how both national and local newspapers covered a part of Appalachia, but that study examined a Kentucky newspaper and The New York 
Times during the War on Poverty. The communications field, as well as the field of Appalachian studies, is lacking in the specific research that this study provides.

This study examines a set of 119 articles, 100 of which are from the Charleston Gazette-Mail and 19 from The New York Times. All units of analysis - single stories were compared and sorted into groups using the constant comparison method (Glaser \& Strauss, 1967) until the model reached theoretical saturation (Glaser and Strass, 1999, p. 61). This was done in three stages (Corbin and Strauss, 1990, p. 12-14): open, axial and selective coding.

During coding, two major emergent categories were discovered: Coal Culture and Suffering, each with multiple subcategories. The research found that, when reporting on the topic of coal, the two newspapers differed in their coverage in that The New York Times was more stereotypical in its reporting about coal, spending almost as much time focusing on the optics of Appalachia and West Virginia and taking care to mention the picket fences, valleys and hollers, while the Charleston Gazette-Mail focused more on the economic aspects of coal mining and relied less on stereotypes. And when it came to Suffering, that was a more significant theme in the Charleston Gazette-Mail's coverage than The New York Times coverage, but that's likely because the Gazette-Mail is the local paper and its job is to cover those issues more closely. That's not to say either paper was more or less stereotypical than the other in terms of suffering. 


\section{Background}

In 1960, Democratic presidential candidate John F. Kennedy came to West Virginia while on the campaign trail ("President John F. Kennedy speaks at the West Virginia State Capitol," 2018). He spent time shaking the hands of coal miners, speaking with the elderly, and visiting the most poverty-stricken areas of the state. He was so taken aback by the poverty in West Virginia that his first executive order once he was elected was to create the food stamps program, the first recipients of which were in McDowell County, West Virginia (Hampson, 2013). It was when he returned as president in 1963, on West Virginia's 100th anniversary, that he delivered the infamous (to West Virginians) line, "The sun does not always shine in West Virginia, but the people always do" (Hampson, 2013).

Since 1960, West Virginia has voted for the Democratic presidential candidate eight out of 14 times ("The American Presidency Project", 2018). The last time West Virginia voted Democrat was Bill Clinton's re-election campaign in 1996. During the 2000 election, in which Republican George W. Bush faced Democrat Al Gore, the state flipped to "red" ("The American Presidency Project", 2018).

Gore, who was known for his environmentalism and concerns about global warming, appeared as a threat to West Virginians' way of life. To the voters, Gore was an environmental "extremist" (Battaile, 2000). They felt that his efforts to stop global warming would be detrimental to the coal industry and mountaintop removal, both vital in West Virginia's economy. Even though United Mine Workers supported Gore, his focus on tackling the energy industry in West Virginia was the tipping point for the state (Battaile, 2000). Almost 52 percent of West Virginians voted for Bush, giving him the 
state's five electoral college votes. Bush won the electoral college 271-266 ("U. S. Electoral College: Historical Election Results 2000-2008", 2008).

In 2008, West Virginia voted red again, choosing Republican John McCain over Democrat Barack Obama by 13 points (Weiner, 2016). It is suspected that not only did Obama's stance on coal deter voters, but, according to the New York Times, two out of 10 white Democratic voters in West Virginia during the 2008 Democratic primary said race - Obama is African American and Hillary Clinton is white — was an important factor when it came to casting their vote; eight out of 10 white Democratic voters in the state backed Clinton (Weiner, 2016). Obama received 35.5 percent of votes in the 2012 election while Republican opponent Mitt Romney — who is white — captured 62.3 percent (Rivera, 2012).

The overwhelming support West Virginia voters expressed for Donald Trump in 2016 - he received almost 68 percent of votes in the Mountain State, according to the Times - earned the state the moniker "Trump Country" (Kaplan, 2016) from media outlets across the country, including the New York Times (Walsh, 2016), the Washington Post (Sinderbrand, 2016), The New Yorker (MacFarquhar, 2016), and Politico (Thompson, 2019). The coverage of "Trump Country" even led to the birth of the news outlet 100 Days in Appalachia — a publication born out of a partnership between West Virginia University's Reed College of Media, West Virginia Public Broadcasting, and the Daily Yonder — whose mission is to "take a closer look at just what makes this region such a flashpoint for so many of the social, economic and political fractures in American communities. If we are indeed 'Trump Nation,' "Appalachia's story is now America's story" (Appalachia, 2017). 
Because national newspapers such as the Times have such societal influences, their coverage brought unprecedented attention to West Virginia, but that coverage is scrutinized for the way it stereotypes West Virginia to try to decode Trump's victory. Historian Jessica Wilkerson pointed out that "many reporters never fail to locate a Trump supporter whose social services are now in jeopardy. This signals to the reader that people in Appalachia acted against their own interests when 90 percent of the region's counties voted for Trump" (Wilkerson, 2017).

Historian Elizabeth Catte said that media coverage of so-called "Trump Country" harkens back to the War on Poverty in the 1960s "when sensational images of the poor filled the pages of newspapers and magazines" and that "often, photographers and journalists capture a version of Appalachia that is not a place - a vast geographic region covering 13 states with more than 25 million people - but a social and moral dilemma that threatens the nation's progress" (Catte, 2018). These images "conceal us from more complex realities" and distort what is actually happening, leading to simplification and exploitation.

This complex situation merits study of how an often-ignored place is covered when abruptly thrust into the spotlight. This study will compare The New York Times coverage of West Virginia during the 2016 presidential election with that of one West Virginia newspaper, the Charleston Gazette-Mail — the publication with the highest circulation rate in the state - from the time Trump was chosen as the Republican nominee up until election day, looking for particular narratives and themes within that coverage. 


\section{Literature Review}

To examine how West Virginia was covered during the 2016 election by both a local newspaper and a national newspaper, this study will employ media theories and concepts, in particular, framing and the concept of Othering. Framing looks at how the media shapes a particular issue or story, which can skew how people think of or view that topic. This can lead to Othering, which is when one person/group views another person/group intrinsically different from themselves, in turn alienating that person/group.

In the following sections, the theory of framing and the concept of Othering will be discussed in depth, highlighting how the two are interconnected using relevant studies and literature.

\section{Appalachian Stereotypes in Outsider Media}

Appalachians, especially West Virginians, are no strangers to framing or othering. In the decades following the Civil War, the idea of Appalachia was first formed when writers presented the region as the "antithesis of an emerging national culture" (Andreescu, 2009, p. 12). But what they failed to acknowledge was that following the Civil War, investors flocked to the region, eager to get their hands on the natural resources like timber, mica, coal, that they could harvest and sell for a large profit. They bought up large swaths of land from residents, essentially forcing them to work for these extraction companies if they wanted to stay in the area. Catte (2018) says the companies justified recruiting locals for their workforce "as benevolent actions that would bring backward mountaineers into their own as equal participants in America's expanding spirit of industry" (p. 37). 
Stereotyping, a generally negative practice, is the formation of "simplified images of members of a group," usually based on obvious "visible differences between the groups...often being pejorative when applied to the out-group" (Fedor, 2014, p. 323). The act of stereotyping is unavoidable, as it is an inherent psychological mechanism of social categorization and allows a person to process information about their environment, but it can be prove to be an obstacle, as it "schematizes and deforms, imposes abusive generalizations and premade ideas, generating fortuitous prejudice" (Fedor, 2014, p. 323).

In analyzing Coal Hollow, a book of photos and oral histories of coalfield poverty in West Virginia by Ken and Melanie Light — both of whom are from California — Scott (2009) found the book perpetuated common stereotypes of Appalachia instead of challenging them, making it seem as if poverty was an exception, not a normal state of affairs, and that the consumers of the book need not worry about that happening to them because they weren't the "less worthy Others" (Scott, 2009). So (2014) compares the difference between how a national newspaper and a local Kentucky newspaper perpetuated poverty stereotypes in Appalachia during the war on poverty in 1964 and 50 years later in 2014. The local newspaper was found to have more of an open mind and be less negative about its community, while the national outlet was more likely to take an overall negative and pessimistic view of the area, as well as focus more on the economics of poverty instead of the cultural and social aspects.

Mass media, such as newspapers and television, are the primary purveyors of stereotypes and Appalachian identity, and Appalachians seem to be an easy target for depicting ignorance and lack of sophistication. In an 1884 article in a West Virginia 
newspaper, the Wheeling Register, farmers who were opposed to deforestation and the construction of a railroad were referred to as "musty elements of old fogyism," serving as "a retardant to progress and prosperity" (Lewis, 1995, p. 303). The first instance of the word "hillbilly" was used in a 1900 article by a New York reporter to describe "the free and untrammeled white citizen, who lives in the hills, has no means to speak of, dresses as he can, drinks whiskey, and fires off his revolver as fancy takes him" (Drake, 2001, p 121). And a Washington Post reporter in 1960 said Appalachia was "the country's worst blighted area" (Andreescu, 2009, p. 12).

In the fall of 2016, in an article for Canada's National Post titled "Donald Trump's pledge to revive mines resonate in down-and-out coal country," author Matthew Fisher tried to do what almost every journalist at the time was doing and interviewed coal miners and poor people in West Virginia to try to understand Trump's appeal in this part of the country. Alongside images of rundown buildings and miners covered in coal dust, Fisher says "there are few better places to understand how Donald Trump could become U.S. president" (Fisher, 2016) than West Virginia, specifically McDowell County. He highlights the population shrinkage and high rates of unemployment while observing that all he hears on the radio is "country music and religious programming." And when he quotes his West Virginia sources, he omits the " $g$ " at the end of words ending in "-ing," replacing it with an apostrophe. In sociolinguistics, this phenomenon is known as "g-dropping" (Yuan, Llberman, 2015) and is often associated with lower socioeconomic status and informal speech. In Fisher's article, he quotes a coal miner who says, "If [Hillary Clinton] gets in there I think the coal miners will have it tough makin' a livin' because of the (Environmental Protection Agency)." 
Appalachia has also been the subject of a few television shows. In 2002, CBS wanted to take a poor Appalachian family and transplant them outside of Appalachia for a year as a sort of remake of The Beverly Hillbillies, sending out flyers in rural areas of Kentucky to find the perfect family to fit their idea of poverty-stricken Appalachians, which outraged residents and activist groups. The backlash was so bad that CBS pulled the plug on their idea (Cooke-Jackson \& Hansen, 2008). More recently, in 2013, MTV ran a West Virginia version of the hit television show Jersey Shore called Buckwild that followed the lives of nine teens in West Virginia. West Virginians did not take kindly to the show, especially U.S. Senator Joe Manchin (D-W.Va.), who said the show played "to ugly, inaccurate stereotypes about the people of West Virginia" (Garland, 2018). Buckwild lasted one month before it was canceled, even though it received high ratings. It appeared the Buckwild producers also planned to release a new show about West Virginia in 2018 called West Virginia Wilder, but it has yet to air as of May 2021 (Garland, 2018). Other shows include The Wild and Wonderful Whites of West Virginia, The Andy Griffith Show, and Moonshiners, all of which rely "on the viewer's inability to tell fact from fiction" only helping to "solidify the image of the culturally impoverished Appalachian as truth in the American imagination (Barnes Trollinger, 2015, p. 43)."

Writers, journalists, and television producers who have continuously propagated Appalachian stereotypes cannot deny that they have benefited greatly, in the form of enhanced careers and notoriety, from their actions. More modernly, J.D. Vance's book, Hillbilly Elegy, a long-time New York Times bestseller and "memoir of a family and of a culture in crisis," became the most popular book for "understanding the lives of disaffected Trump voters" (Catte, 2018, p. 7) following the 2016 election. Vance 
constructed Appalachia as an all-white region run amok with "resentment and poor life decisions" and believed the only way to improve its condition was to "prioritize the economic investments of our social betters" (Catte, 2018, p. 8).

Vance's perceived reality of Appalachia, as well as that of television stations like CBS and MTV and beyond, is riddled with stereotypes and misgivings, often blaming Appalachians for their own plight instead of acknowledging the institutional roadblocks that have made it more difficult for them to advance. These stories provided a framework for how people who consumed this media view an entire nation.

\section{Framing and News Coverage}

Entman (2007) defines framing as the "process of culling a few elements of perceived reality and assembling a narrative that highlights connections among them to promote a particular interpretation," which, in turn, shapes how people perceive a certain message. Framing theory also explains the media's role in amplifying and defining an issue. According to Haas, Mattson, Jones \& Morris (2013, n.p.), "As the media foregrounds certain issues, a plethora of other issues are relegated to the background of public attention." In other words, the media determines what it believes to be the most vital issues and consigns the rest by giving it less attention.

Farnsworth \& Lichter (2013) examined how the Times covered Obama during his first two years in office — referred to as a "presidential honeymoon" — and compared that to coverage of previous presidents, finding that the positive framing of Obama during his honeymoon period lasted longer than that of the three presidents in office before him. Framing can also be used to examine concepts such as gender. Meeks 
(2013) examined how the New York Times framed gender in coverage of Hillary Clinton and Sarah Palin in the 2008 presidential election, finding that Palin was spoken about in a warmer manner than Clinton. Goldenberg and Kahn (1991) also looked at gender and assessed how male and female candidates were covered differently during Senate races between 1982-1986 and found that female candidates received less coverage than their male counterparts, but the coverage they did receive was more negative than the men's and relied more on their viability as a candidate instead of their stances on issues.

An example of how outside media organizations framed a disaster in West Virginia is the Sago Mine Disaster of 2006, in which an explosion killed 12 miners. Reporters flocked to the scene, and the bulk of the news coverage became focused on the grief of the families who awaited answers about their loved ones. About 48 hours after the explosion, as families gathered in a nearby church, rescue crews phoned to inform them that all but one miner had survived the blast and rescue efforts were underway. Newspapers across the country printed headlines like "Miracle in Mine" (Folkenflik, 2006) and “'Alive' Miners Beat Odds" (Folkenflik, 2006). The families rejoiced, their celebrations making national news, and they prepared the church as a triage area for the injured miners. After a few hours of joy and relief, the families were dealt devastating news: The original report from rescue crews was wrong, and all but one miner had died - something NPR later confirmed (Folkenflik, 2006) that mine officials knew for quite some time before informing the families. Their triumph turned to tragedy live on-air for all the nation and world to see, relegating the pervasive and longstanding issues of mine safety to the back burner. 
Following the announcement of this mass casualty event, the media performed an exercise in framing by portraying the reactions as "a melodramatic response triggered by grief, not as a series of reactions compelled by the often abusive tension between mine operators and the communities that served as their workforce" (Catte, 2018, p. 20-21), and journalists spoke about the men as if their deaths were a sort of spiritual lesson - they sought out family members of the deceased miners and inquired about their favorite scripture passages to analyze them for any suggestion of impending death - not the result of decades of maltreatment of miners and lackluster safety regulations at the hands of coal executives (Catte, 2018).

Following Entman's (2007) definition of framing, these news outlets selected pieces of the aftermath and used them to form a spiritual narrative about the afflicted people of West Virginia and the deaths of their loved ones, taking away from the need to dig deeper into the coal mining industry to examine and expose any corruption or malpractice.

\section{Othering}

"By not being Others we define ourselves. We have always done so" (Barkan, 1980, p. 180).

Framing theory selects and hones in on specific aspects of the reality in question, while concurrently averting attention from other aspects (Entman, 1993). It shapes the way readers/viewers perceive a certain topic and/or person, leading not only to stereotyping and judgment, but also a practice known as "Othering". The concept of Othering is "an exercise in power" (Breen, Devereux, and Haynes 2006, p.13) and can 
be defined as "the simultaneous construction of the self or in-group and the other or outgroup" (Brons, 2014, p. 70) via identifying acceptable traits the in-group possesses and the out-group lacks. This self-delegated in-group has the power to construct said groups, while the out-group is simply constructed.

According to Brons (2014, p. 104), othering, a skill observed in children as young as three years old (Lam, Seaton, 2016), is a "self-serving stigmatization...through misinterpretation" and the "attribution of some undesirable characteristic to the other or out-group" that leads to the idea that the other, or out-group, is somehow inferior or "radically alien" (Brons, 2014). Othering justifies exclusion, discrimination, and subjection because it forms a boundary between the in-group and out-group, leading to implicit ideas and feelings of superiority and inferiority.

"Otherness" is considered newsworthy by the mass media. The divergence from what is seen as the norm attracts attention and mystifies the out-group. Almost always, othering is a negative practice. In Ireland newspapers' 2002 coverage of immigration, for example, asylum seekers were deemed threats by news outlets, who referred to immigrants in terms of the diseases they might carry, their sexual deviancy, and extremism of their beliefs (Breen, Devereux, and Haynes 2006). They were considered a threat to the Irish way of life.

In the late 1800s, the Times framed the Shakers, a religious sect dating back to the 1700s (Riccardi, 2010). The Shakers were ostracized and often viewed as abnormal by the rest of society. The Times' articles often included negative language and phrasing, portraying the Shakers as being in opposition to the "normal" values of American society. This created two types of boundaries: the "negative, rhetoric-based, 
media-driven, social boundary" (Riccardi, 2010, p.109) by the Times to exclude the Shakers from normal American society; and "the spiritual, social, and physical boundary" (Riccardi, 2010, p. 109) created by the Shakers' ideas about celibacy and "dirt." In the late 19th and early 20th centuries, African Americans and Italians were also targeted by the Times, such as when the paper published articles that advertised lynchings of African Americans, using words like "brutes" and "troublesome Negroes" to label the victims. Other articles said Italian children were "filthy" and "verminous," and southern Italians were a "low and ignorant" class; one article even compared Italian immigrants to rattlesnakes (Staples, 2018).

When it comes to big-city news coverage of small-town violence, there appears to be an unconscious desire to idealize and frame small towns in a way that aligns with American culture, ignoring the more complex issues that may be at play in that community, such as racism, politics or crime (Franks, 2013). Understanding "the other" can and will always be a challenge for journalists, but acknowledging and tackling personal biases is one way to remedy that. According to Cunningham (2003), "we also need reporters to acknowledge all that they don't know, and not try to mask that shortcoming behind a gloss of attitude, or drown it in a roar of oversimplified assertions" (n.p.). In Deciding What's News, Herbert Gans wrote,

"Journalists cannot exercise news judgment without a composite of nation, society, and national and social institutions in their collective heads, and this picture is an aggregate of reality judgments ... In doing so, they cannot leave room for the reality judgments that, for example, poor people have about America; nor do they ask, or even think of asking, the kinds of questions about the country that radicals, ultraconservatives, the religiously orthodox, or social scientists ask as a result of their reality judgments" (Gans, 1979, p. 201)." 
In other words, journalists must make an effort to understand all facets of a society, including those who are seen as the "other" and the realities they face.

While mass media has been practicing the concept of othering against people and groups of all ethnicities, religions, genders, etc. from all across the country for centuries, othering has an especially lengthy history in Appalachia. Writings from 19thand 20th-century authors offer an in-depth look at how Appalachia was portrayed.

\section{Othering of Appalachia}

Appalachia has often been used "as a mirror that reflects something troubling, but recognizable back to the nation" (Catte, 2018, p. 9). By the late 1800 s and early 1900s, novelists and writers heavily adopted Appalachia's otherness in their work to add "dramatic tensions" (Smith, Fisher, et al, 2010), which only further reinforced the preexisting stereotypes about Appalachia. In an essay about his travels throughout Kentucky in the late 1800s, author Will Wallace Harney (Harney, 1873) spoke about the landscapes and people he encountered, remarking on their "quaint speech and patient poverty" (p. 473). To him, the poverty-stricken children in this region were "pitiful" yet "brave" (p. 431), and when he visited the home of an elderly African American couple, he intimated that the man, who was quite old and living in abject conditions, would be better off if he received help from "the great liberator, Death" (p. 431). He noted that the "natives of this region are characterized by marked peculiarities of the anatomical 
frame," with their elongated bones, "disproportion of their extremities", and sharp facial structures akin to that of President Abraham Lincoln (p. 431).

Other writers relied heavily on Appalachian stereotypes, like John R. Fox, who wrote The Little Shepherd of Kingdom Come, in which he perpetuates the "idea that Appalachians were ignorant of slavery and monolithically supported the Union during the Civil War," and The Trail of the Lonesome Pine, in which he focused on Appalachia's isolation and "primitive otherness" and told the story of a man who tries to turn a mountain girl into a sophisticated woman, a metaphor for what the rest of the country wanted to do to Appalachia.

In his 1966 book, Yesterday's People: A Contemporary Life in Appalachia, missionary Jack E. Wells claims that "mountain people do both think and hope for many things—but in a different way from middle class people" (Weller, 1966, p. 3), and Harry M. Caudill, author of Night Comes to the Cumberlands, believed that Appalachians "were stubborn, opinionated, and sometimes cruel" (McKinney, 2010, p. 29), and that they needed these qualities to "survive on the tooth-and-talon frontier" (McKinney, 2010, p. 29), relying heavily on the idea that Appalachians are deviant and prone to feuds and violence, a stereotype formed during the Civil War when loyalties were tested and the region lacked consistent governmental control. Caudill also believed early settlers in Appalachia were "degenerate social outcasts of the English society" who lacked "will and ambition" (Brashear, 2016). William Goodell Frost, a Greek scholar and president of Kentucky's Berea College from 1890 to 1920, descibed Appalachians as "our contemporary ancestors," and an "anachronism" who were what remained of the frontiersmen who first settled America (McKinney, 2010, p. 29). 
Acting Against Self-Interest

Journalists parachuted into the Appalachian region during the 2016 election West Virginia specifically — to find out why the occupants of the region emphatically put their support behind Trump, a man to whom they could not relate. Trump is a wealthy, thrice-married businessman who has spent most of his life establishing casinos and high-end real estate. West Virginia is impoverished and has low education rates (McCann, 2021), as well as heightened rates of obesity (CDC, 2021) and related health problems, and a dying coal industry. In 2017, West Virginia had the highest rate of drug overdose deaths in the country (CDC, 2017), and people were looking for a solution in the form of radical change. Many West Virginians likely saw the "unconventional Trump candidacy" as the "change people were looking for" (Chisholm, 2018). What they didn't realize was that they were voting for a candidate whose policies would only exacerbate the issues that plagued them.

Acting in one's own self-interest is "the motivation to maximize material resources, promote one's health and to minimize material harm and avoid harm to one's health" (Kim, 2014, p. 101), which encompasses a wide variety of behaviors. It's also "the hedonistic motive to pursue feeling good and avoid feeling bad" (Kim, 2014, p. 101), which refers to the "desire to promote pleasurable psychological states" (Kim, 2014 , p. 101), and means that engaging in any behavior that makes an individual subjectively feel good is acting in self-interest, even if it doesn't change wealth status or that individual's health. Another definition is "the psychological impact of being involved 
in a particular outcome" (Kim, 2014, p.101). If someone is personally affected by something, they are automatically self-interested.

Some may question why a state would vote for a candidate whose policy ideas would not stand to benefit it. For example, West Virginia used to be a booming coalproducing state. But in the last few decades, coal production has decreased drastically (U.S. Energy Information Administration, 2020) as cleaner sources of energy have emerged, such as wind and solar, both of which can help combat climate change. Coal, on the other hand, contributes to climate change (International Energy Agency, 2019), a problem that affects everyone on the planet. Because Trump touted that he could bring back coal jobs (Fears, 2017), people in this economically deficient state put their hope in and supported him, believing they were acting in their own self-interest.

While there is existing research on how self-interest plays into political beliefs and voting, it's hard to determine exactly how they interchange. For example, Lau \& Heldman (2009) and Sears \& Funk (1990) found that political ideology — liberalism vs. conservatism — tends to be a "stronger predictor of support for government-provided health insurance or privatized health care than self-interest” (Kim, 2014, p. 108). Whether or not respondents did have self-interest or were underinsured was nowhere near as strong a predictor (Lau \& Heldman, 2009; Sears \& Funk, 1990). "Political ideology is also a stronger predictor of policies that would guarantee jobs for everyone, even among those who are unemployed" (Kim, 2014, p. 108).

\section{Research Questions}


West Virginia was a frequent subject of discussion during the 2016 election. It was dubbed "Trump country" and used to understand the political climate that made journalists want to know why poor, rural, white people showed support for Trump. But just how much did both national and local media rely on/perpetuate stereotypes?

(RQ) How will the local news outlet and the national news outlet differ in their portrayals of West Virginia during the selected time frame? Because, according to the literature (So, 2014), the local newspaper is likely to be more open-minded and less pessimistic in its coverage of West Virginia, while the national outlet may be less openminded and more pessimistic. Because the New York Times is considered "outsider media," it's also likely that they may rely more on stereotypes in their coverage than the Charleston Gazette-Mail.

\section{Methods}

This study used grounded theory and its constant comparison method to focus on the framing of West Virginia in the New York Times and Charleston Gazette-Mails coverage of the state during the 2016 Presidential Election.

Grounded theory is the collecting and analyzing of qualitative data to form theories grounded in that data. Sociologists Barney Glaser and Anselm Strauss (1967) first developed grounded theory, which they describe as "how the discovery of theory from data—systematically obtained and analyzed in social research—can be furthered" (p. 1). The approach, a hybrid of theory and method that aims to generate theory, allows for flexibility and creativity when examining data. This develops theory that is always relevant to the data it examines because it is drawn from - and thus grounded in - 
that data

The Times has the highest circulation in the United States ("Top 15 U.S. Newspapers by Circulation," 2018) and is likely to have had a large influence on U.S. opinion leaders and other news outlets (Djerf-Pierre \& Shehata, 2017); the Charleston Gazette-Mail has the highest circulation of any in-state newspaper in West Virginia (West Virginia Secretary of State, 2018). The national paper has the power to influence national opinions and viewpoints of society to a greater extent than many other sources, laying the framework for how people may view an entire state. The state paper has similar power within the confines of West Virginia, influencing how residents may view both local and national issues, such as in Djerf-Pierre \& Shehata's (2017) study examining the differences between local and national news coverage during the Iraq War.

Units of analysis for this study were stories in the designated publications and date range that involved West Virginia's part in the 2016 election. This included the West Virginia gubernatorial campaign due to the friendship between President Trump and current West Virginia Governor Jim Justice — for example, Governor Justice announced he was switching his party registration from Democrat to Republican at a Trump rally in Huntington, West Virginia, where President Trump referred to Governor Justice as "big Jim" (Beech \& Rampton, 2017). On the Nexis Uni database, "West Virginia" was used as the search term, then the results were narrowed down using the exact time frame from when Trump was nominated at the Republican National Convention on July 19, 2016, until Election Day, Nov. 8, 2016, and publications (The New York Times and The Charleston Gazette-Mail) selected for this study. The "search 
within results" tool was then used to search the word "elections". This final search produced 360 results, but these were sorted to remove articles such as obituaries, sports, letters to the editor, repeat articles, and "This Week in WV" stories. This left 119 results: 19 from the New York Times and 100 from The Gazette-Mail. Of these 119 articles, 39 were editorials or opinion pieces.

All units of analysis - single stories - were compared and sorted into groups using the constant comparison method (Glaser \& Strauss, 1967) until the model reached theoretical saturation, the state at which "no additional data are being found....and nothing remains but to go on to new groups" (Glaser and Strass, 1999, p. 61). The researcher sought to develop as many categories as possible while constantly comparing each unit of data to all others (Hallberg, 2006). These comparisons helped the researcher "in guarding against bias, for he or she is then challenging concepts with fresh data" (Corbin and Strauss, 1990, p. 9).

To apply constant comparison to this study, each story was examined for emerging concepts while continuously being compared to the previously examined stories and concepts until a hypothesis has been formulated. This process of theoretical coding has three stages (Corbin and Strauss, 1990, p. 12-14): open, axial and selective coding. The first stage is open coding, where the researcher codes the data in every way possible and groups the data with similar events, actions, or interactions to establish preliminary categories. During axial coding, the second stage, categories found during the first stage of coding are linked to subcategories. In the final stage, selective coding, "categories are organised around a central explanatory concept" (Corbin and Strauss, 1990, p. 14). 
As an example of constant comparison in action, Barrett and Levin (2013) used it to identify Romance Narratives in the PG Era of World Wrestling Entertainment (WWE) Programming. Using storylines in the WWE programs "Monday Night Raw" and "Friday Night Smackdown!" over a six-month period, the researchers first open-coded the transcripts from WWE shows line-by-line to identify preliminary narratives within the data (e.g. "Female Revenge" and "Female Emotional Instability"). They then axially coded within those categories to clarify any connections within and between them (e.g. they identified frequent connections between female revenge and female emotional instability, leading to the "Woman Scorned" narrative). Finally, the researchers used selective coding to coalesce all data, ultimately identifying six dominant narratives and 21 core themes.

In Armstrong, Wood, and Nelson's (2010) study comparing female news professionals in local and national news during the Iraq War, they found that local news stations had a higher proportion of female newscasters covering both "hard" (such as war) and "soft" news than national news. The researchers used taped segments from the national networks $A B C, N B C$, and $C B S$, as well as three affiliate stations of those networks in a Midwestern market, for their samples. Fox was excluded because its national and local segments were not on the same channel. The authors were careful to mention that because Fox was left out, it could have skewed their results, as the national broadcast tends to feature female newscasters. They also point out that the Midwestern market from which they pulled their stations was liberal-leaning, which may played some role in why there were more female newscasters.

Research such as these provide a framework for properly executing grounded 
theory. Constant comparison and systematic coding were used to establish categories and relationships from which an explanatory theory is then drawn. That new theory was then used to compare and contrast local and national newspapers in their coverage of West Virginia.

\section{$\underline{\text { Results }}$}

The goal of this research was to determine how two newspapers, the Charleston Gazette-Mail and The New York Times, portrayed West Virginia leading up to the 2016 presidential election. There were 119 articles total, with 100 from the Charleston Gazette-Mail and 19 from The New York Times. There were two main emergent categories: Coal Culture and Suffering. Based on the findings and data, the results indicate that there was a strong emphasis on the emergent category of Coal Culture, with the Times more likely to rely on stereotypical ideas surrounding coal and coal miners and the Gazette-Mail focused on the economic aspects of coal. In the category of Suffering, both publications had similar proportions of articles that fit within that theme (see Table 1).

\section{Emergent Categories}

Two major emergent categories were discovered: Coal Culture and Suffering, each with multiple subcategories. For Coal, there were four subcategories: the Plight of the Coal Miner, Coal Country, Coal's Collapse, and Safety and Damage. For Suffering there were two: Hellhole and the Drug Epidemic. Because the goal of this research was identifying themes and how they were used, these categories were not mutually 
exclusive. Although it was not common, some stories were coded within more than one category because they exhibited themes that could not be confined to one category.

Table 1

Category breakdowns across publications

\begin{tabular}{|l|c|c|c|}
\hline & $\begin{array}{c}\text { Charleston Gazette- } \\
\text { Mail }\end{array}$ & $\begin{array}{c}\text { The New York } \\
\text { Times }\end{array}$ & Total \\
\hline Coal & $\mathbf{3 6}(\mathbf{3 6 \% )}$ & $\mathbf{3 ( 1 5 . 8 \% )}$ & $\mathbf{3 9 ( 3 2 . 8 \% )}$ \\
\hline $\begin{array}{c}\text { The Plight of Coal the } \\
\text { Miner }\end{array}$ & $7(7 \%)$ & $1(5.3 \%)$ & $8(6.7 \%)$ \\
\hline Coal Country & $9(9 \%)$ & $1(5.3 \%)$ & $10(8.4 \%)$ \\
\hline Coal's Collapse & $12(12 \%)$ & 0 & $12(10.1 \%)$ \\
\hline Safety \& Damage & $9(9 \%)$ & $1(5.3 \%)$ & $10(8.4 \%)$ \\
\hline Suffering & $\mathbf{3 4 ( 3 4 \% )}$ & $\mathbf{3 ( 1 5 . 8 \% )}$ & $\mathbf{3 7}(\mathbf{3 1 . 1 \% )}$ \\
\hline Hellhole & $26(26 \%)$ & $3(15.8 \%)$ & $29(24.4 \%)$ \\
\hline Drug Epidemic & $8(8 \%)$ & $1(5.3 \%)$ & $9(7.6 \%)$ \\
\hline
\end{tabular}

\section{Coal Culture}

There was a significant emphasis on coal, which was mentioned in a total of 39 articles (32.8\% of the total) from both the Charleston Gazette-Mail (36\% of the articles in that publication) and New York Times (15.8\% in that publication). In the first round of open coding, the subcategories of the Plight of Coal Miners, Coal Country, Coal's Collapse, and Safety and Damage were discovered. These were then coalesced into the main category of Coal Culture during selective coding.

The subcategory of the Plight of Coal Miners earned its name because one can't 
talk about coal without mentioning the people who mine the coal. Several articles focused solely on the miners, and much of the language used when referring to coal miners mentioned them being out of work or unemployed. In one New York Times article, titled "Alienated and Angry, Coal Miners See Donald Trump as Their Only Choice," the miners spoke about how they or their friends have lost jobs, cars and homes because of mine closures, and they see Trump as the only viable candidate because of his promise to "bring back coal." The article mentioned Bo Copley, "the area's most famous out-of-work miner," best known for challenging Hillary Clinton during her 2016 visit to West Virginia on comments she made about putting coal companies out of business. Days after Clinton's visit to West Virginia, Copley received a standing ovation at a Trump rally and told a reporter that "Trump is a break from the status quo, which promises the moon but doesn't deliver."

Ten articles made reference to Coal Country, whether it was that phrase specifically or similar words such as "legacy of coal" or "backdrop of the legacy of coal". The "Coal Country" title refers to how West Virginia and its neighboring Appalachian states are often referred to as such, suggesting that is what the area is most known for. In one Charleston Gazette-Mail editorial written by a West Virginia state senator and a Maine state senator, the concept is mentioned in passing: "We are both Americans, but couldn't be any more different: Coal country vs. Maine's shoreline. Democrat vs. Republican." In a New York Times article, the author speaks about his trip from "coal country in West Virginia to the Southwestern borderlands," and says "Trump supporters have casually dismissed the litany of insults and outrage that has characterized his campaign." In these examples, coal is used as a signifier and as a label, marking and 
detailing West Virginia, in only a few words, as if it and coal were synonymous. There is an argument to be made that the title "Coal Country" itself is an exercise in stereotyping. It's widely known that the industry, which has depleted the state's economy, is in decline. Between 2011 and 2016, Appalachia as a whole lost more than 33,000 mining jobs (Appalachian Regional Commission, 2017). By labeling a place "Coal Country," one may surmise or assume that either the area is chock full of coal miners or that everyone is poor. Neither is true.

Twelve articles focused on the Collapse of Coal and other extraction industries, and all came from the Gazette-Mail. Coal is a dying industry, with production hitting its lowest levels in four decades as of 2019 (Grandoni, 2020), so it's only natural some of the articles in this study would focus on that aspect. In an article detailing United States Sen. Shelley Moore Capito's (R-W.Va.) support for Donald Trump, the reporter says "West Virginia's economy has been in a tailspin as the population shrinks and ages, fossil fuel prices plummet and a combination of cheap natural gas, depleted seams and federal regulation decimate the coal industry." In another Charleston Gazette-Mail article about the United Mine Workers union decrying a mine safety bill passed by one of the state's candidates for governor, the reporter writes that while both candidates proudly claim to be pro-coal, "the long-term forecasts that show West Virginia coal is unlikely to rebound." At a September 2016 rally in Pittsburgh, Pennsylvania, thenPresident-elect Donald Trump promised to "end the war on coal and the war on miners," something that earned him the favor of Appalachians and West Virginians. Coal's Collapse had the most articles out of all the Coal Culture subcategories, indicating that it is presented as the most significant topic surrounding coal. 
The last Coal Culture subcategory had to do with Safety and Damage, referring to the effects coal has had on the people, economy, and landscape/natural resources of West Virginia. In an editorial for the Charleston Gazette-Mail, the author compares and contrasts different counties in West Virginia, pointing out how some are better off financially, while their neighboring counties are suffering, for which mining is partly to blame. "Black lung death and disability, environmental degradation and what should be viewed as nothing short of criminal UMWA pension mismanagement are but three examples ... from this tragic backdrop of the legacy of coal." In a New York Times article about Vermont's wind projects, the reporter mentions people opposed to the project and how mountaintop mining has scarred West Virginia. While there was no significant use of stereotyping or othering by either newspaper in this subcategory, that doesn't mean those phenomena did not exist at all. One specific example of Othering has to do with black lung disease, a problem most Americans will never have to grapple with. When it comes to this fact alone, West Virginians and other coal-producing states are automatically the "Other".

Overall, in the Gazette-Mail's article about Coal Culture, they focused less on stereotypes and othering and more on the economic and political ramifications of coal, while the Times did rely on stereotypes and othering. Aside from the one article that mentioned mountaintop removal, the Times devoted its coverage more to the miners themselves and how angry they were. More than $20 \%$ of the articles across both publications that make up Coal Culture also fit within more than one subcategory, illustrating how important and pervasive this topic is presented as in West Virginia.

\section{Suffering}


The second emergent category was Suffering. Both newspapers spent a significant amount of time on how West Virginia was falling behind or hurting in some way. Thirty-seven articles (31.1\% of the total) fell within the Suffering category, with 34 (34\% of that publication) coming from The Charleston Gazette-Mail and three (15.8\% of that publication) coming from The New York Times. Within Suffering, there were two subcategories: "Hellhole" and "the Drug Epidemic." As stated in the previous section, there were some Suffering articles that fit within both categories and were coded as such.

The title "Hellhole" comes from an editorial published in The Charleston GazetteMail that details how West Virginia was "near last in many economic categories" and that it was listed "as a top five hellhole every year" until 2015 by the American Tort Reform Foundation's Judicial Hellhole Report. Hellhole articles frequently mention the state's poverty and how far down on each national list West Virginia stands compared to other states when it comes to things like innovation and education. All of those topics were grouped together under Hellhole because they were used to frame West Virginia as the worst, or close to the worst.

Both papers make several references to unemployment numbers and the health status of the state's residents. In a New York Times article, the reporter says, "unemployment, at 12 percent, is more than twice the United States average. Cash-forgold stores crowd alongside lawyers' offices and gun dealerships...Many residents scrape by on food stamps." The mention of the unemployment rate specifically lends itself to Othering, as the reporter focused on how poor West Virginia is compared to the rest of the country, signalling it out as the "other". There's a long history of people, 
especially the media, pointing out the poverty in West Virginia and Appalachia, as if that's only an issue in that specific region. During the War on Poverty, photographers flocked to the area to take photos of miners covered in coal dust, children bespeckled in dirt, and families living in ramshackle homes, something that can be referred to as "poverty porn". These sensational images created this idea that all people in West Virginia and Appalachia are poor, an idea that still persists to this day, and that their poverty makes them stand out from the rest of the country.

Two separate Charleston Gazette-Mail editorials that were hopeful for a Hillary Clinton presidency said that Clinton acknowledged the "suffering" and "problems" of West Virginia and would be the best candidate to tackle those issues. Some articles detail how West Virginians "have been screwed over and they are scared and desperate. The middle and working classes are collapsing into the poverty class," and the "population shrinks and ages, fossil fuel prices plummet and a combination of cheap natural gas, depleted seams and federal regulation decimate the coal industry." West Virginia is portrayed as poor, lagging, and depleted compared to the rest of the country; again, making it the "other".

The next subcategory is the Drug Epidemic. As previously mentioned, in 2017 West Virginia had the highest rate of drug overdose deaths in the country, and the years previous were not much different. In a Charleston Gazette-Mail column, written by someone whose stepdaughter lost a friend to drugs, the author says he's angry about the state's "inability to deal with the scourge that is destroying families and communities throughout the state." Other Charleston Gazette-Mail articles say the state has been "ravaged by the drug epidemic" and that unemployment leads to a "downward spiral" of 
"drugs, crime and broken families."

The Gazette-Mail had more than twice the percent of Suffering articles as The New York Times. The Times did tend more toward stereotypical uses of Suffering in ways that presented residents as "Other", in one example referring to Mingo County, West Virginia, "a picture of social and economic" decay that is "steeped in the lore of corruption, coal and violence" and where obesity and drug overdose rates are some of the highest in the country. The Gazette-Mail more broadly covered Suffering as a fact and stereotyping or othering were far less notably present.

\section{Theoretical and Research Expectations}

The observation of the use of framing and stereotypes led to the discovery of emerging categories of Coal Culture and Suffering, which were unexpected, yet unsurprising. There was no preconceived notion that the newspaper would focus so much on those topics, but considering the academic literature, it comes as no surprise. Not all coverage drew on the emergent themes of Coal Culture and Suffering, but the findings suggest that the two newspapers were more focused on the problems of West Virginia than anything else.

The study of heuristics approaches problem-solving by finding a sufficient, but not perfect, way to reach an explanation or goal for a particular issue or idea (Bordalo et al, 2015). Specific to this study is the idea of representativeness heuristics, or "a strategy for making categorical judgments about a given person or target based on how closely the exemplar matches the typical or average member of the category" (American Psychology Association, n.d.). In other words, people make judgments about 
others based on preconceived notions about that person or group. For example, someone may assume that all Irish people have red hair, even though only $10 \%$ of Irish people do (Bordalo et al,, 2015). So while red hair is more common amongst Irish people than other demographics, it's not true overall. This can be applied to how people view West Virginia and Appalachia as home to "the most impoverished, undereducated and unhealthy citizens in the nation." While it is true that West Virginia falls toward the bottom of the list in most of those categories, it does not follow that all West Virginians are uneducated, poor, and unhealthy; media framing of the region as such is inaccurate and simplistic.

In The New York Times, one article said that those who were angry and felt politically alienated, "[offered] such a simple electoral calculus" — establishing them as the "Other" or the outsider. They were framed as a specific group, apart from the rest of the country, to help explain or understand the draw to Trump. The reporter focused on the unemployment rates, drug problems, and the social and economic decay of the state. But he also took care to mention the "tight-knit rural values" and the "picturesque district of twisting valleys [that are] steeped in the lore of coal, corruption and violence" — pointing out positive generalizations of the state in conjunction with the negative where "racial epithets ... ring out openly" and confederate flags fly proudly. In a Charleston Gazette-Mail editorial, the writer said. "You have to worry what [Tump's] campaign is doing to his businesses. Angry unemployed white people are not a great demographic for high-end stuff. Maybe instead of selling luxury condos and golf memberships, he'll have to turn to trailer parks and tattoo parlors." Not only is the author painting all West Virginians as "angry unemployed white people" and insinuating that 
no one in the state likes "high-end stuff," they're also suggesting that trailer parks and tattoo parlors are not desirable places to be.

The Charleston Gazette-Mail was more blunt in its descriptions and stereotyping — "angry," "undereducated and unhealthy," "trailer parks and tattoo parlors" — while the New York Times was more nuanced and intermixed all of those ideas along with less negative remarks about the state's "picturesque" and "tree-studded" hills and valleys and the "tight-knit rural values." Both outlets, however, made references to West Virginians feeling angry and politically alienated, as if they are seen as less important than the rest of the country. They feel left out and isolated, making them the "other" both at the hands of the newspapers, as well as themselves.

While the literature made some mention of coal because it is an intrinsic part of West Virginia's history and culture (Catte, 2018; Andreescu, 2009; So, 2014), it provided no indication coal would be such a distinctive category during the selected time frame as discovered in this research. The two newspapers were similar in their coverage because they both spent considerable time covering coal in some capacity. They differed in that the New York Times's coverage was more stereotypical in its articles about coal, focusing on how angry miners were. While the Charleston GazetteMail focused more on the economic aspects of coal mining and relied less on stereotypes, the Times explicitly said, "but this is not just about economics. West Virginia's coal country is part of the broader white working-class vote that has coalesced around a single candidate, Mr. Trump, like never before."

But the discovery of Suffering was not surprising, as a lot of the literature alludes or outright mentions the state/region's history of poverty and misfortune (Catte, 2018; 
Cooke-Jackson \& Hansen, 2008; Scott, 2009). Suffering was a more significant theme found in the Charleston Gazette-Mail's coverage than the New York Times. When comparing the proportions of each newspaper's articles in this category, the GazetteMail devoted more than twice as much coverage to this topic.

\section{Discussion}

The purpose of this research was to compare how both a local and a national newspaper covered West Virginia during the 2016 Presidential Election, with the goal of discerning the differences between the frames used in their coverage The findings suggest that the Charleston Gazette-Mail and the New York Times differed in their coverage when it came to both Coal — where the Times's reporting relied more on stereotypes and Othering than did the Gazette-Mail's - and Suffering, where the only significant difference between the two newspapers was that the Gazette-Mail clearly devoted more of its coverage to that category than the Times.

The discovery of the emergent category Coal is significant, as the two papers reported on a topic deeply intertwined within West Virginia's history. From when West Virginians were forced off their lands by investors who wanted to harvest the coal and timber and were then made to work for the coal companies (Catte, 2018), to the Battle of Blair Mountain (Andrews, 2018) in the early 1900s, coal remained an integral stitch in the fabric of West Virginia. Coal production started to decline in the late-20th century and people lost their jobs (Kolstad, 2017), and then the Sago Mine Disaster happened in 2006 (Folkenflik, 2006). Coal continued to play a major role in the state in the past few decades, during which a once staunchly blue state turned red in favor of coal- 
friendly policies promised by politicians.

It's thus not surprising that the Gazette-Mail's coverage focused less on stereotypes than on the political ramifications of coal, as well as the effects on the economy, speaking about the "tumble" of the coal industry and how "no one in West Virginia who has any knowledge of the coal industry expects coal to ever again be the overwhelmingly dominant source for electric power generation." Twelve percent of the Gazette-Mail articles coded for this study mentioned Coal's Collapse, and $0 \%$ of the New York Times article addressed that. One Gazette-Mail editorial even posed a question to the then-presidential candidates, asking what they planned to do to help bring jobs back to an area grappling with a dying industry and the loss of jobs. These particular findings are in line with So (2014), who found that the national newspaper was likely to be more pessimistic about poverty, while the local paper was more likely to have an open mind.

This study found that, across both publications, much of the focus on coal miners was about how they are out of work or struggling to find and keep work. They were often referred to as angry and as "looking for a path forward" from their economic positions, and references were made to an "inchoate rage" felt amongst the miners, mostly written by The New York Times. This plays on old trends of stereotyping in Appalachia, with miners frequently being portrayed as upset or bitter over their situation and that they had a "hostile attitude to all supervision" (Lewis, 1993, p. 304). In the literature, Appalachians were referred to as stubborn and opinionated (McKinney, 2010, p. 29), and author J.D. Vance said that Appalachia ran amok with "resentment and poor life decisions" (Catte, 2018, p. 8). Unlike some of the academic literature that 
researched media blaming the miners and/or Appalachians for their situations (Lewis, 1993 \& 1995; Catte, 2018; ), the articles used for this study, from both publications, did not blame the miners for their situations or claim that, but instead acknowledged the industry's decline, with several referring to them as laid-off coal miners and saying "a downturn in the market won't mean much to the unemployed coal miners of West Virginia" (Keillor, 2016). They weren't being blamed for their economic situation; outside forces were.

Many of the articles analyzed for this study fell under the category of Suffering, in that the other people of the state, as well as the state itself, were featured in the reporting in regards to economic problems, family situations, and the drug epidemic ravaging the state. One New York Times article features a West Virginia man who was formerly a miner making $\$ 30$ an hour a few years prior, but at the time of the article he was making a third of his previous wage by working security at a local Walmart. He said that "when the mines go down, it hurts everything" (Walsh, 2016). But it wasn't just the miners of West Virginia that were portrayed in terms of their misfortunes. In two proHillary Clinton editorials for the Gazette-Mail, the authors claim Clinton would be the best person to try to soothe and fix the suffering and problems of "places like West Virginia," and in the span of just a few sentences in a single New York Times article, the reporter touches on some of the most significant issues facing West Virginia:

"Williamson itself, a town of 3,000, is a picture of social and economic decay. Unemployment, at 12 percent, is more than twice the United States average. Cash-for-gold stores crowd alongside lawyers' offices and gun dealerships. Rates of heroin overdoses and obesity are among the highest in America. Many residents scrape by on food stamps.

In the surrounding hills, abandoned coal mines hum with the noise of 
ventilation pumps still circulating oxygen through the empty shafts, in the hope that they might one day be reopened" (Walsh, 2016).

In the literature, there are many references to West Virginia being impoverished, "down-and-out" (Fisher, 2016), and having "no means to speak of" (Drake, 2001, p 121). The media has long had a penchant for putting Appalachia's poverty on display. In 1967, Hugh O'Connor, a Canadian filmmaker and his crew descended on a rural Kentucky town to document the area's living conditions during the War on Poverty, and he was shot and killed by a local landowner in the process (Rosenfeld, 2000). During JFK's visit to West Virginia in the early '60s, he was — most likely strategically — photographed with the impoverished people of the "economically distressed, overwhelmingly Protestant, hardscrabble state" (JFK Library, 2010).

While the articles used for this study were not holding flashing neon signs that said "POOR" over the state of West Virginia, they did devote a significant amount of time to the topic of poverty, as well as the state's rank in areas like innovation (last), educational progress (last), and economy (next to last). In other words, West Virginians were "othered" and, again, made to seem as if the state is outside the norm because they are not as healthy, wealthy, or educated as the rest of the country; this makes them stand out from the rest of America. They also discussed the opioid/drug epidemic and how it's a "downward spiral" ravaging the state and destroying families. This harkens back to the literature, which says that during the War on Poverty in the 1960s, "sensational images of the poor filled the pages of newspapers and magazines" (Catte, 2018). Even author Henry Caudill, who often lamented Appalachia for its poverty and used the region's misfortunes as fodder for his books, would take people on "poverty 
tours" near his home in Kentucky. And in the 1960s, Life published a slew of black and white photographs in its magazine, with accompanying text that said, "Their landscape is a man-made desolation of corrugated hills and hollows laced with polluted streams. The people, themselves often disease-ridden and unschooled, are without jobs and even hope...Unless the grim chain [of unemployment and lack of education] can be broken, a second generation coming of age in Appalachia will fall into the same dismal life a life that protects them from starvation but deprives them of self-respect and hope" (Domini, 1964). This research found that while the media is still subscribing to the amplification of poverty, these newspapers are more stating the fact that there is poverty/misfortune and exploring its causes than putting blame on the people themselves. Although they don't do it to the same extent as people like Caudill and Domini, nor do they rely on histrionics to make their point.

\section{Limitations and Future Research}

For this study, one of the limitations was the small sample size of articles from the New York Times; out of 119 articles, only 19 were from the Times. It was somewhat difficult to compare the local and national papers when there was such a discrepancy in the sample size from each because there was much more to work with from the Charleston Gazette-Mail, and the New York Times sample was smaller because it made up all the available articles that focused on West Virginia during the time frame. A potential topic for future research would be to examine how frequently the New York Times covers West Virginia and to what extent the lack of coverage constitutes Othering. The less data available to work with, the harder it is to end up with 
meaningfully descriptive findings. But the idea behind this study was to examine how one national newspaper and one local newspaper differed in their coverage of West Virginia. Future research could include articles from another prominent national newspaper or scale down the number taken from the local newspaper. It could also examine how editorials versus straight news stories differed in their coverage of West Virginia when it comes to stereotyping, othering, or framing.

Another limitation was the time frame from which the samples were taken, which was good because it allowed us to see how the state was covered during a very specific and tumultuous period in American history. But future research could go on to expand the time frame, which would allow for more articles from the Times as well as provide the opportunity to discover other emergent themes. For future research, another researcher could expand the time frame from earlier in the election cycle and possibly extend it beyond Election Day.

Another topic for future research could be to examine how The New York Times covered West Virginia prior to 2016 and compare it to this study to see how or if it was different. 2016 was a unique year, so examining years prior would give an insight to see how things have changed.

The media is guilty of foregrounding the problems plaguing West Virginia and Appalachia instead of emphasizing how the region is prospering or what it's getting right. CBS, MTV, J.D. Vance, and both national and local news media are quick to share and promote imagery depicting a poor, dirty, unhealthy, uneducated, and downtrodden state. By doing this, the rest of the nation is viewing the state through the framework provided to them by the media, missing what's left behind, and ultimately 
being presented with stories and images of the "other". In this study, the researcher discovered West Virginians being referred to as "politically alienated" and "angry unemployed white people" who live in places "where racial epithets...ring out openly." Many articles pointed out how badly the state is doing (i.e. "Suffering") in almost every measurable category - innovation, education, wealth, etc. The researcher also discovered just how important coal was during this time frame, with one-third of the total articles dedicated to that topic. Most of the framing in that category came in the form of labelling coal miners as "angry," an old stereotype, as well as referring to West Virginia as "Coal Country," also a stereotype. While no media source is completely free from bias, this research and its findings suggest that a national newspaper is going to have a different, and likely more stereotypical, view on a specific region than a local paper. 


\section{Bibliography}

The American Presidency Project. (2018). Presidency.ucsb.edu.

American Psychological Association. (n.d.). APA Dictionary of Psychology. American

Psychological Association. https://dictionary.apa.org/representativeness-heuristic.

Andreescu, Viviana. (2009). Violent Appalachia: The media's role in the creation and perpetuation of an American myth. Journal of the Institute of Justice \& International Studies. 9. 62-75.

Andrews, E. (2016, August 25). The Battle of Blair Mountain. History.com.

https://www.history.com/news/americas-largest-labor-uprising-the-battle-of-blair-mountain.

Appalachia, 1. D. (2017, December 07). Hello, world.

Appalachian regional Commission. (2017, June). Maps: Addressing Economic Challenges in Appalachia's Coal-Impacted Communities.

Armstrong, C. L., Wood, M. L. M., \& Nelson, M. R. (2010). Female News Professionals in Local and National Broadcast News During the Buildup to the Iraq War. Journal of Broadcasting \& Electronic Media.

Barkan, E. (1994). Post-Anti-Colonial Histories: Representing the Other in Imperial Britain. Journal of British Studies, 33(2), 180-203. doi:10.1086/386050

Barnes Trollinger, E. R. (2015). The Hard Work Is Done In The Looking: Representations Of And Responses To Appalachia In Popular Culture. University of Mississippi.

Barrett, B., \& Levin, D. (2014). What's Love Got to Do with It? A Qualitative Grounded Theory Content Analysis of Romance Narratives in the PG Era of World Wrestling Entertainment (WWE) Programming. Sexuality \& Culture, 18(3), 560-591

Battaile, J. (2000, November 05). THE 2000 CAMPAIGN: WEST VIRGINIA; Gore Is Trying to Catch Up In Democrat-Dominated State. The New York Times.

Beech, E., \& Rampton, R. (2017). At Trump rally, West Virginia governor switches parties. Reuters.

Bordalo, P., Coffman, K., Gennaioli, N., \& Shleifer, A. (2015, May). Stereotypes. Harvard University.

Breen, M.J., Haynes, A. and Devereux, E. (2006), 'Fear, Framing and Foreigners: The Othering of Immigrants in the Irish Print Media'. International Journal of Critical Psychology, 16, 100-121.

Brons, Lajos. (2014). Needing the other: the anatomy of the Mass Noun Thesis. Argument. 4. 103122.

Brons, Lajos. (2015). Othering, An Analysis. Transcience, a Journal of Global Studies. 6. 69-90. 
CDC. (2017). Drug Overdose Mortality by State.

CDC. (2021, March 31). Adult Obesity Prevalence Maps. Centers for Disease Control and Prevention. https://www.cdc.gov/obesity/data/prevalencemaps.htmI\#: :text=35\%25\%20or\%20more\%20adults\%20had,and\%20the\%20West $\% 20(27.4 \% 25$ ) .

Catte, E. (2018). Passive, poor and white? What people keep getting wrong about Appalachia. The Guardian.

Charmaz, K. (2006). Constructing Grounded Theory: A Practical Guide Through Qualitative Analysis.

Colistra, R. (2010). The Rumble and the Dark: Regional Newspaper Framing of the Buffalo Creek Mine Disaster of 1972. Journal Of Appalachian Studies, 16(1/2), 79-100.

Cooke-Jackson, A., \& Hansen, E. K. $(2008,08)$. Appalachian Culture and Reality TV: The Ethical Dilemma of Stereotyping Others. Journal of Mass Media Ethics, 23(3), 183-200.

Corasaniti, N. (2016, May 05). In West Virginia, Ebullient Donald Trump Takes On Everything From Hillary Clinton to Hair Spray. The New York Times.

Corbin, J. \& Strauss, A. (1990). Grounded Theory Research: Procedures, Canons, and Evaluative Criteria. Qualitative Sociology, 13 (1), 3-23.

Cosgrove, B. (2020, January 16). The War on Poverty in the Pages of LIFE: Appalachia Portraits, 1964. LIFE. https://www.life.com/history/war-on-poverty-appalachia-portraits-1964/.

Cunningham, B. (2003). Re-thinking Objectivity.

Disney, L. R. (2017). Associations Between Humanitarianism, Othering, and Religious Affiliation. Social Work \& Christianity, 44(3), 60-74.

Djerf-Pierre, M., \& Shehata, A. (2017). Still an agenda setter: Traditional news media and public opinion during the transition from low to high choice media environments. Journal of Communication, 67(5), 733-757.

Drake, R. B. (2001). A history of Appalachia. Lexington, KY: University Press of Kentucky. 
Entman, R. M. (1993). Framing: Toward clarification of a fractured paradigm. Journal of Communication, 43(4), 51-58

Entman, R. (2007). Framing Bias: Media in the Distribution of Power. Journal of Communication, 57(1), pp.163-173.

Farnsworth, S. J., \& Lichter, S. R. (2013). An Extended Presidential Honeymoon? Coverage of Barack Obama in the New York Times during 2009 and 2010. Politics \& Policy, 41(3), 447-463.

Fears, D. (2017, March 29). Trump promised to bring back coal jobs. That promise 'will not be kept,' experts say. Retrieved from https://www.washingtonpost.com/news/energyenvironment/wp/2017/03/29/trump-promised-to-bring-back-coal-jobs-that-promise-will-not-bekept-experts-say/

Fedor, CG. (2014). Stereotypes and Prejudice in the Perception of the "Other", Procedia - Social and Behavioral Sciences. Volume 149. 2014. Pages 321-326.

Fisher, M. (2016, November 02). Matthew Fisher: Donald Trump's pledge to revive mines resonates in down-and-out coal country. Retrieved from https://nationalpost.com/news/world/matthew-fisher-donald-trumps-pledge-to-revive-minesresonates-in-down-and-out-coal-country

Folkenflik, D. (2006, January 5). Sago: The Anatomy of Reporting Gone Wrong. NPR. https://www.npr.org/templates/story/story.php?storyld=5126627.

Frank, R. (2009). When Bad Things Happen in Good Places: Pastoralism in Big-City Newspaper Coverage of Small-Town Violence*. Rural Sociology, 68(2), 207-230.

Gabriel, T. (2014, April 21). 50 Years Into the War on Poverty, Hardship Hits Back. The New York Times.

Gabriel, T. (2016, May 11). Bernie Sanders Wins West Virginia, Prolonging Race With Hillary Clinton. The New York Times.

Gans, H. (1979). Deciding What's News. New York: Random House.

Garland. M. (2018, May 18). 'Buckwild' producers back in WV filming new series. Charleston Gazette-Mail. 
Glaser, B. \& Strauss, A. The Discovery of Grounded Theory: Strategies for Qualitative Research. 1999. 60-112.

Grandoni, D. (2020, July 29). Analysis | The Energy 202: U.S. coal production hit its lowest point in last four decades. The Washington Post.

https://www.washingtonpost.com/politics/2020/07/29/energy-202-us-coal-production-hit-its-

lowest-point-last-four-decades/.

Hallberg, L. (2006). The Core Category of Grounded Theory: Making Constant Comparison. International Journal of Qualitative Studies on Health and Well-being 1. 141-148.

Hampson, R. (2013). When W.Va. lost its voice: JFK's death still resonates. USA TODAY.

Harney, W. (1873). LIPPINCOTT'S MAGAZINE. Retrieved November 17, 2020, from

https://www.gutenberg.org/files/13964/13964-h/13964-h.htm

HARTMAN, I. C. (2014). West Virginia Mountaineers and Kentucky Frontiersmen: Race, Manliness, and the Rhetoric of Liberalism in the Early 1960s. Journal Of Southern History, 80(3), 651-64.

Healy, P. (2008, May 14). Clinton Beats Obama Handily in West Virginia. The New York Times.

Haas, E. J., Mattson, M., Jones, C., \& Morris, P. L. (2013). Newspaper Coverage of Motorcycle Accidents: A Content Analysis from a Media Framing Perspective with Implications for Practice. International Journal Of Motorcycle Studies, 9(2), 1

lea. (2019, March). Global Energy \& CO2 Status Report 2019 - Analysis. IEA.

https://www.iea.org/reports/global-energy-co2-status-report-2019.

Kaplan, T. (2016, March 04). This Is Trump Country. The New Yorker.

Kahn, K. F., \& Goldenberg, E. N. (1991). Women Candidates in the News: An Examination of Gender Differences in U.S. Senate Campaign Coverage. Public Opinion Quarterly, 55(2), 180199.

Kim, A. (2014). The curious case of self-interest: inconsistent effects and ambivalence toward a widely accepted construct. Journal for the Theory of Social Behaviour, 44(1), 99-122.

https://doi.org/10.1111/jtsb.12032

Kolstad, C. (2017, March 1). What Is Killing the US Coal Industry? SIEPR.

https://siepr.stanford.edu/research/publications/what-killing-us-coal-industry.

Lam, V., Seaton, J. (2016). "Ingroup/Outgroup Attitudes and Group Evaluations: The Role of Competition in British Classroom Settings", Child Development Research, vol. 2016

Lau, R. R., \& Heldman, C. (2009). Self-Interest, Symbolic Attitudes, and Support for Public Policy: A Multilevel Analysis. Political Psychology, 30(4), 513-537. 
Lewis, R. (1993). Appalachian Restructuring in Historical Perspective: Coal, Culture and Social Change in West Virginia. Urban Studies, 30(2), 299-308. Retrieved April 20, 2021, from http://www.jstor.org/stable/43198067

Lovell, C. (2018). A Sense of Place on Top of the World.

MacFarquhar, L. (2016). In the Heart of Trump Country. The New Yorker.

Meeks, L. $(2013,08)$. All the Gender That's Fit to Print. Journalism \& Mass Communication Quarterly, 90(3), 520-539.

McCann, A. (2021, February 16). Most \& Least Educated States in America. WalletHub. https://wallethub.com/edu/e/most-educated-states/31075.

McHugh, M. (2012). Interrater reliability: the kappa statistic. Biochemia Medica, 276-282. doi: 10.11613/bm.2012.031

McKinney, G. (2010). Reconstructing Appalachia: The Civil War's Aftermath (SLAP A., Ed.). University Press of Kentucky. Retrieved November 17, 2020, from http://www.jstor.org/stable/j.ctt2jctwj

Nelson, Thomas E., Rosalee A. Clawson, and Zoe M. Oxley. 1997. "Media Framing of a Civil Liberties Conflict and Its Effects on Tolerance." American Political Science Review 91: 3: $567-$ 583.

President John F. Kennedy speaks at the West Virginia State Capitol. (2018). Wvculture.org.

Riccardi, S. A. (2010). "Cheerless Asceticism": How the New York Times Portrayed the Shakers from 1851 to 1899. LOGOS: A Journal Of Undergraduate Research, 3102-109.

Rivera, R. (2012). 2012 Election Results: West Virginia. The New York Times. https://www.nytimes.com/elections/2012/results/states/west-virginia.html

Rosenfeld, M. (2000, July 11). Killing in Kentucky: Out-of-Focus 'Camera'. The Washington Post. https://www.washingtonpost.com/archive/lifestyle/2000/07/11/killing-in-kentucky-out-of-focuscamera/ae02ea91-5f94-41a8-9cb7-666dd31b7269/.

Rutenberg, J. (2008, May 14). 'Almost Nominee' Status Keeps Obama in Limbo. The New York Times.

Sears, D. O., \& Funk, C. L. (1990). The limited effect of economic self-interest on the political attitudes of the mass public. The Journal of Behavioral Economics, 19, 247-271.

SMITH, B., FISHER, S., OBERMILLER, P., WHISNANT, D., SATTERWHITE, E., \& CUNNINGHAM, R. (2010). Appalachian Identity: A Roundtable Discussion. Appalachian Journal, 38(1), 56-76.

Retrieved November 17, 2020, from http://www.jstor.org/stable/41320248

Scott, R. (2009). The Sociology of Coal Hollow: Safety, Othering, and Representations of Inequality. Journal Of Appalachian Studies, 15(1/2), 7-25. 
Sinderbrand, R. (2016). The Daily Trail: Why Sanders claimed one of Clinton's biggest 2008 states. The Washington Post.

So, G. (2014). "From 'Pockets of Poverty' to Potential Prosperity in Appalachia: Examining Mass Media Narratives of Poverty Stereotypes in Appalachia." Elon Journal of Undergraduate Research in Communications, 5(2).

Staples, B. (2018). Opinion | When Southern Newspapers Justified Lynching. Nytimes.com.

Thompson, A. (2019). Trump backers applaud Warren in heart of MAGA country. Politico.

Top 15 U.S. Newspapers by Circulation. (2018).

U. S. Electoral College: Historical Election Results 2000-2008. (2008).

U.S. Energy Information Administration. (2020). (rep.). Annual Coal Report 2019. Retrieved from https://www.eia.gov/coal/annual/pdf/acr.pdf

Walsh, D. (2016). A Reporter Retraces His Steps Through Trump Country. The New York Times.

Weiner, R. (2016, May 10). Flashback: The time a felon took 41 percent against President Obama in West Virginia. The Washington Post.

Weller, J. E. (1966). Yesterdays people. Life in contemporary Appalachia. Lexington: University of Kentucky Press

Wilkerson, J. (2017). What the Media Misses When It Sees Appalachia as Just 'Trump Country.' Rewire.News.

Winning West Virginia-JFK's Primary Campaign. Winning West Virginia-JFK's Primary Campaign | JFK Library. (n.d.). https://www.jfklibrary.org/visit-museum/exhibits/past-exhibits/winning-westvirginia-jfks-primary-campaign.

Yuan, J., \& Liberman, M. (n.d.). Automatic Detection of "g-dropping" in American English Using Forced Alignment. University of Pennsylvania. 